\title{
Geological modeling and upscaling of the Ronier 4 block in Bongor basin, Chad
}

\author{
Mahamat Tahir Abdramane Mahamat Zene ${ }^{1} \cdot$ Nurul Hasan $^{2} \oplus \cdot$ Jiang Ruizhong ${ }^{1} \cdot$ Guan Zhenliang $^{3} \cdot$ Christ Trang $^{4}$
}

Received: 30 November 2018 / Accepted: 5 June 2019 / Published online: 20 June 2019

(c) The Author(s) 2019

\begin{abstract}
The study focuses on building a 3D-dimensional model for using well log data of 3 wells to enable a better understanding of the reservoir characteristics and evaluation of the hydrocarbon potential in the field of Ronier in the Bongor Basin, Chad. These data are used to build a Lithofacies model, property model, the permeability model and the saturation model which are the parameters that describe the reservoir. Indeed, the accuracy to quantify the geological reserve of Ronier 4 reservoir block depends on the estimation of these values. The result of geological modeling and upscaling of the Ronier 4 block of Ronier oilfield is presented systematically. In this work, a Sequential Gaussian Simulation (SGS) algorithm under the phase control based on the collocated co-Kriging is adopted and the models of porosity, permeability and saturation are established. Lithofacies model has sand (0) content of $66.69 \%$ mostly the first layer, while the code (2) shale content $12.15 \%$ mostly concentrated in the center, north and south. Finally, the code (3) sand content is $21.16 \%$. The NTG distribution is highly concentrated in the north, center and south (1) and 0.7 on average, while the lowest range is 0.1 . The study shows a good permeability range between 460 to 1200 and $500 \mathrm{mD}$ on average. The porosity distribution mainly distributed between 17 to 27 and $19 \%$ on average. These indicate that it has good reservoir properties. The 3D developed geological model provides the basis for calculating the Oil Initially in Place (OIIP) volumes of hydrocarbons.
\end{abstract}

Keywords Geological modeling · Central African Rift Zone (CARZ) · Modeling uncertainty · Upscaling

\section{Introduction}

Nurul Hasan

nurulhasan@asme.org

Mahamat Tahir Abdramane Mahamat Zene

1b1702005@s.upc.edu.cn

Jiang Ruizhong

jrzhong@126.com

Guan Zhenliang

guanzl@cug.edu.cn

Christ Trang

christ@doncomputing.com

1 College of Petroleum Engineering, China University of Petroleum (East China), Qingdao, China

2 PCE, Universiti Teknologi Brunei, Mukim Gadong A BE1410, Brunei Darussalam

3 Faculty of Earth Resources, China University of Geoscience (Wuhan), Wuhan, China

4 Don Computing, 17/31 Queen St, Melbourne 3000, VIC, Australia
The exploration for Bongor Basin was started in the 1970s. The first exploratory well of Naramay 1 well was drilled in the basin. A total of 2 wildcat wells without oil and gas discovery had been drilled until the year 2004. Ronier 1 oil was drilled in January 2007 and obtained a daily oil production of $267 \mathrm{bbl} / \mathrm{d}$. In 2008, Ronier 4 was successively drilled and obtained more than $1000 \mathrm{bbl} / \mathrm{d}$. These facts indicate that Bongor Basin has the potential for commercial exploitation. After half of the year 2008, there was a significant breakthrough which laid the foundation for millions of tons of productivity, and it was transformed into development (Bai et al. 2015). The compiling work for Ronier oilfield was started in August 2007 and ended in April 2009. Up to now, there have been five (5) oil-bearing structures: Baobab, Ronier, Kubla, Mimosa and Cailcedra. All were discovered together, and all of them are located in the mid-north of Bongor Basin. Bongor Basin is located at the crossing part of Central Africa rift zone and West Africa rift zone. It is a Mesozoic-Cenozoic rift basin, 
which is developed from the effects of the Central Africa shear zone. Bongor Basin is a half graben, with a length of about $300 \mathrm{~km}$ and a width of about $75 \mathrm{~km}$. Sediments are mainly the classic rock of lower Cretaceous and Cenozoic, the maximum sediment thickness of the lower Cretaceous is $7000 \mathrm{~m}$, and the main lithology is continental mudstone, shale, sandstone and silt stone. According to the seismic (Lorentzen et al. 2018) interpretation results, Bongor Basin was divided into two sets of the structural layer as shown in Figs. 1 and 2. The lower structural layer belongs to a Cretaceous system, and the upper structural layer is in Tertiary. Ronier 3-D areas are situated in the north slope of Bongor Basin, takes the major fault of the basin margin as the north boundary, connects Kubla structure in the east, faces Naramay structure on the west and borders on the south of the dominant sag (1-2). The 3D area for the studied block is $503 \mathrm{~km}^{2}$ (Dou et al. 2018). The current research is based on the following formation structures: KublaI 1, KublaI 2, Mimosa I and Mimosa II.

Few parameters directly influence (Genik 1992), and realistically all the parameters cannot be accessed. The purpose of this paper is to build a geological modeling (Hourfar et al. 2018) and upscaling (Misaghian et al. 2018) of the Ronier 4 block. The following formation structures: KublaI 1, KublaI 2, Mimosa I and Mimosa II are the structure of interest. The geological model and upscaling of Ronier 4 block cover: seismic data, perform well correlation, build structural models, property model (porosity, water saturation and permeability).
Fig. 1 The tectonic position and geological map of Bongor Basin [2]
Fig. 2 The structural division of the Bongor [7] basin, Ronier 2, Ronier 1, Ronier 2, Ronier 3, Ronier 4, Ronier 4-1, Ronier S1, Baoba 1, Kubla 1, Cailcedra 1, Mimosa 1, Mimosa 2 oil well of (Mimosa oilfield)
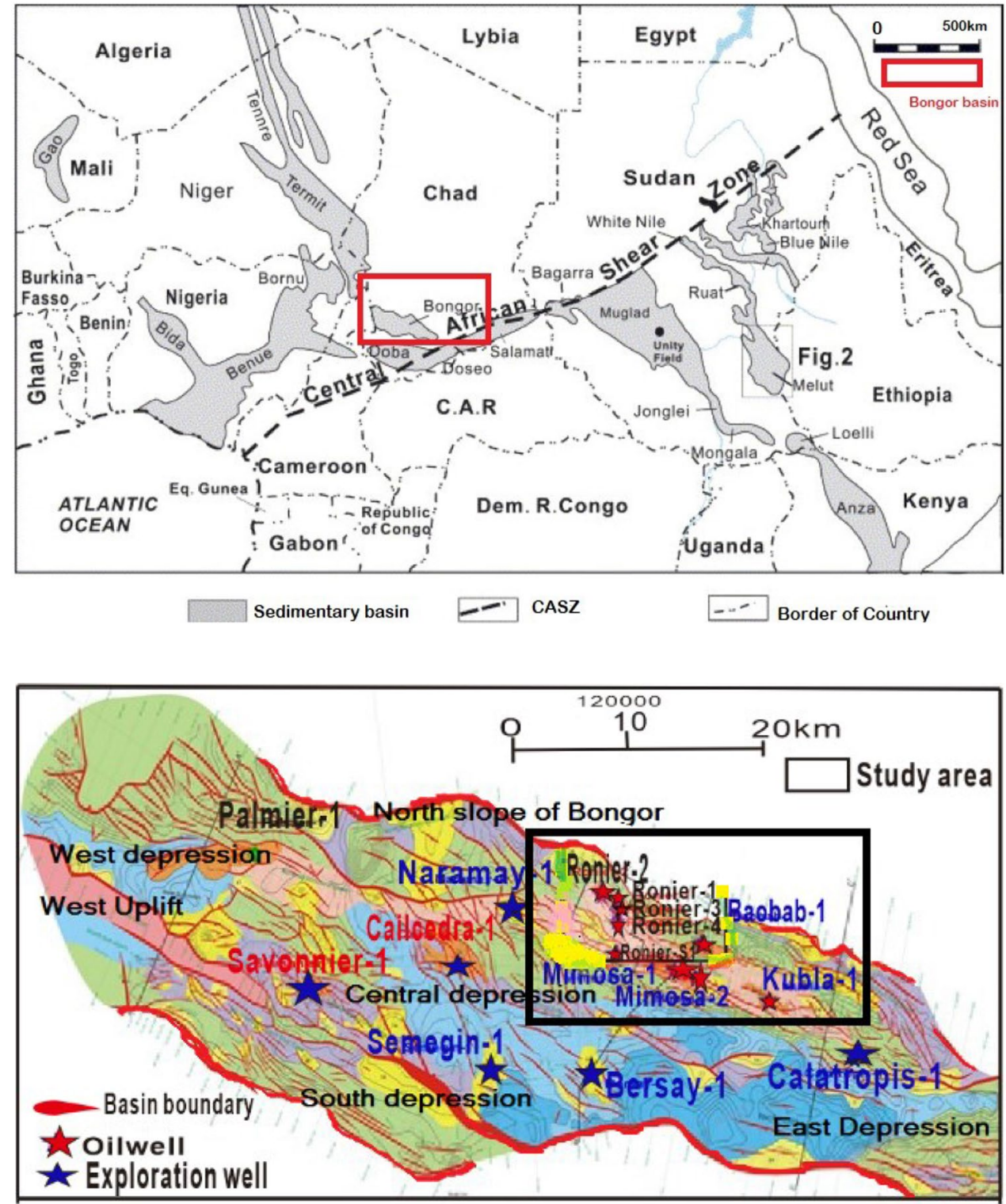


\section{Computational domain}

From Fig. 1, Bongor Basin is designed by the extensional movement of the Central African Shear Zone (CASZ); more information on shear zone can be found here (Khan et al. 2003; Junyi and Hasan 2018. This is detached from the Doba-Doseo Basin to the south by a basement high, and this is a huge scale of domain (Sern et al. 2012) for modeling. The Bongor Basin, small NW-SE trending half graben with the planar spindle-shaped geometry (Fig. 1). The Bongor Basin has gone through several tectonic phases including three rift chapters and two capsizal phases.

During the primary Cretaceous retro, the CASZ was fully triggered as one segment of the aulacogen arrived into the African continent, forming a series of rift basin clusters; then, it gradually waned after complete parting of the African and South American plates (Shellnutt et al. 2015).

\section{Computational methodology}

Data used for this study is the well log data; more info will be presented on type of data later. First, the surface is modeled, proceeded by the facies, thereafter the petrophysical parameters (porosity, permeability, water saturation, Net-ToGross (NTG) NTG). Variograms are applied to demonstrate the divergence between data points as a function of distance. It is the most widely used tool to investigate and model spatial variability of various reservoir attributes [2]. Furthermore, the variogram is necessary for the stochastic modeling of surface as well for the petrophysical.

On the other hand, the variogram is not necessary for the facies. While in this study, we have considered the Sequential Gaussian Simulator (SGS) for modeling the facies there upon the variogram. Eight wells drilled in the Ronier oilfield are: Well Ronier S1 (TD 2099 MD), Ronier C-1 (TD 1793 MD), Ronier CN-1 (TD 2093 MD), Ronier 4 (TD 1835 MD), Ronier 3 (TD 2099 MD), Ronier 1 (TD 2144 MD), Ronier 4-1 (TD 1835 MD) and the well of Ronier 4-2 (TD 2292 MD). Before constructing a static model, based on a previous structure map of the Ronier 4 block, KublaI 1, KublaI 2, Mimosa I and Mimosa II were digitized to create surface and polygons faults. The workflow used to model and upscale the block of Ronier 4 block of Ronier oilfield in the Bongor basin. A 3D model was built to interpret various parameters as following: seismic data, perform well correlation, build structural models, property model. Model processed into different stages (Fig. 3) as described below the workflow.

Geologic research result shows that Block of Ronier 4, Kubla I have a high production layer, including two oil-water contacts. The first is Kubla I-1, its oil-water contact depth is $1469 \mathrm{ft}$. The second is Kubla I-2, and its oil-water contact depth is $1503 \mathrm{ft}$. The oil-water contact depth of Mimosa I is

Fig. 3 Workflow and software usage

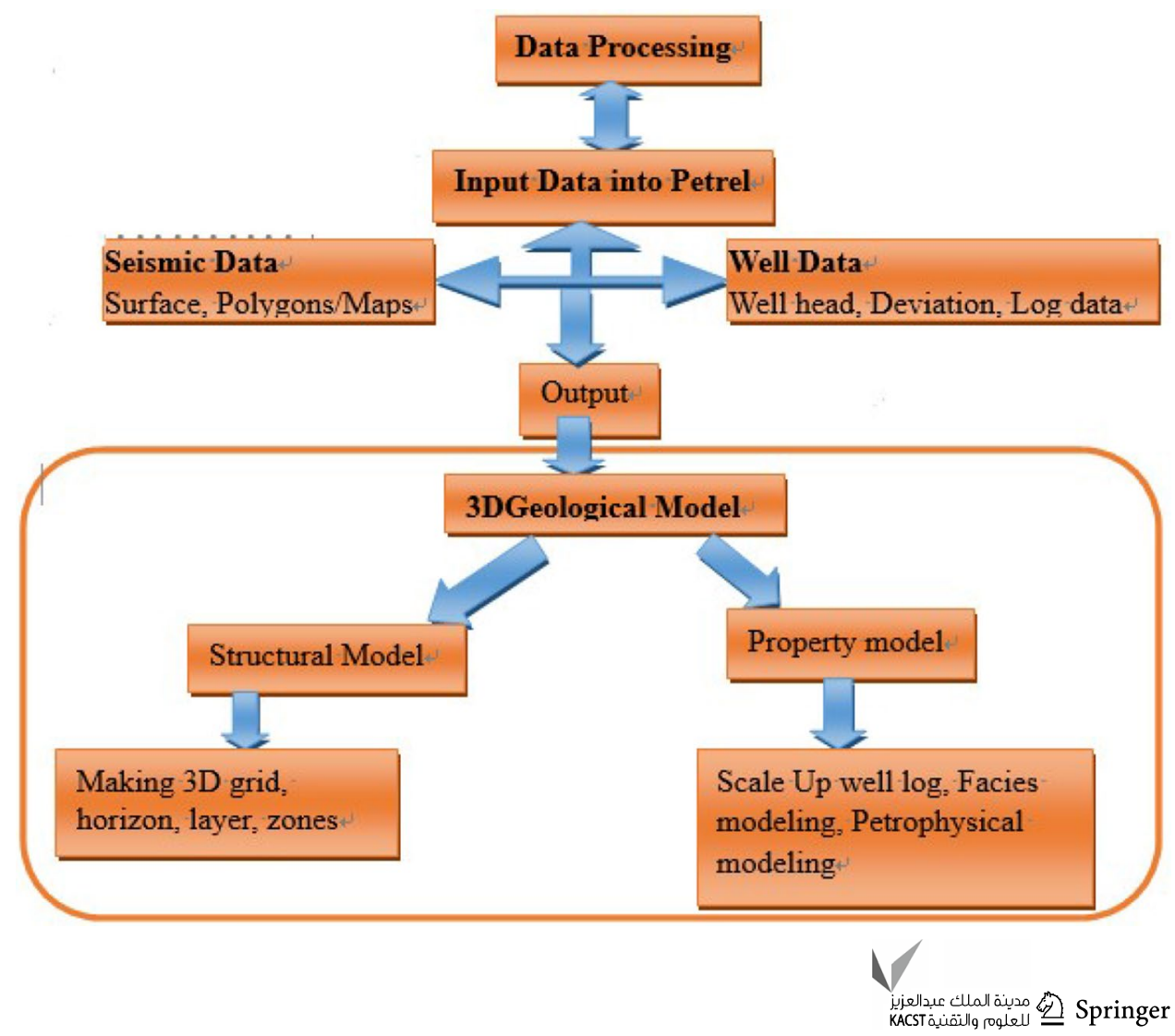


1671; oil-water contact depth of Mimosa II is $1800 \mathrm{ft}$. The reasonable static geological models (Tan et al. 2017) were created for Block Ronier 4 of Kubla I-1, KublaI 2 as well as Mimosa I and Mimosa II of Ronier 4. Mimosa I and Mimosa II structures are found in the well of Ronier 4-2. The loaded data of the established well work region includes well curve, sand body and single well microfacies interpretation of the oil, gas and water and stratigraphic data. An elevation correction is made for each well to ensure that the oil reservoir data tally with the actual underground situation. The seismic inversion includes sand-clay property body, porosity, permeability (Sedaghat et al. 2018), saturation and clay content volume. The cross-well seismic data are loaded according to the standard SEG-Y format. The layers and faults of seismic interpretation defined corresponding loading format according to the interpretive system (Figs. 4, 5, 6, 7, 8, 9, 10, 11).

Digitized figure interpretation ensures the consistency of the comprehensive geological understanding with the seismic interpretation results. Following the combined relation among the faults, the connection is made for faults, and finally, a three-dimensional fault model is established (Figs. 4, 5, 6, 7, 8, 9, 10, 11).

The types of the oil reservoir in Ronier 4 block are mainly fault-block reservoirs controlled by the structure and then were lithological structural oil reservoirs. For the Ronier 4 block, faults are made based on the digitization of a previous polygon fault. In total, there are four faults in the Ronier 4 block as following: Fault1, fault2, fault3 and fault4.
The fault direction is from north to south. The stratigraphic framework model describes the space combination relation between faults and strata. Using the fault model, seismic interpretation, the structural model of sedimentation unit, is established.

The single-layer framework model means the geologic model regarding the single layer as the basic unit. The single-layer model is the basis of sedimentary microfacies model. The modeling uses the method of calculating the top and bottom structural planes according to the strata thickness under the constraint of the top and bottom structural morphology so that a precise three-dimensional framework model is made. Ronier 4 reservoir is divided into three single layers. After the layering of the single layer, the planar grid scaling in Block Ronier 4 is performed (Witt et al. 2007; Zhalehrajabi et al. 2014). The longitudinal grid scaling is divided as $0.3 \mathrm{~m}$ according to the minimum single sand body thickness of various sedimentary units (Ishak et al. 2018; Khan et al. 2001). The total number of the cells is $143 \times 55 \times$ $3=23595$.

\section{Results and discussion}

The Oil Initially in Place (OIIP) has a direct relation with various static parameters of the reservoir geological model. The porosity, permeability, saturation and spatial distribution of clay content of the reservoir geological

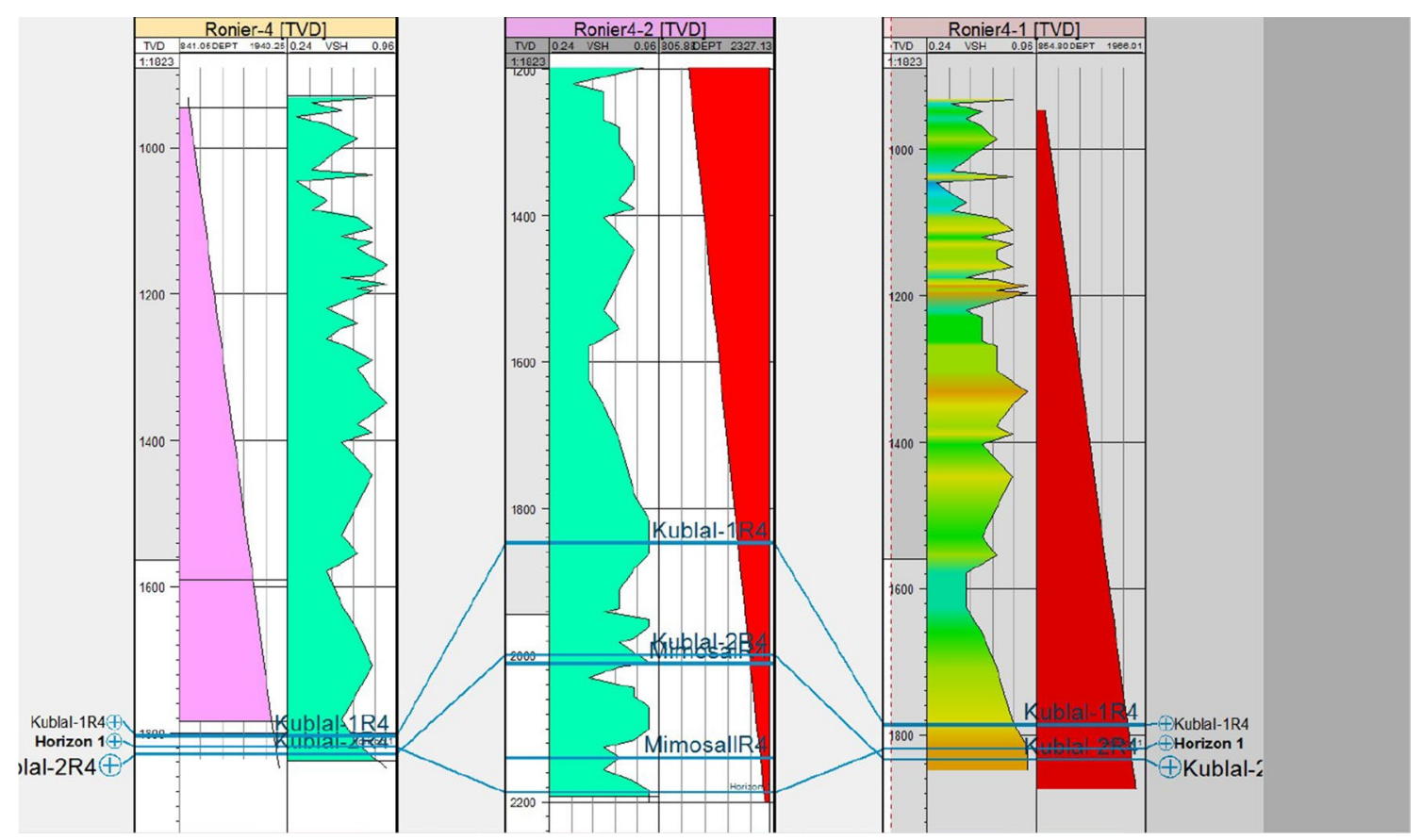

Fig. 4 The well section of Ronier 4 (from left depth, Vsh to the right), Ronier 4-2 (from left Vsh to the right depth), Ronier 4-1 (from left Vsh, to the right is depth) 


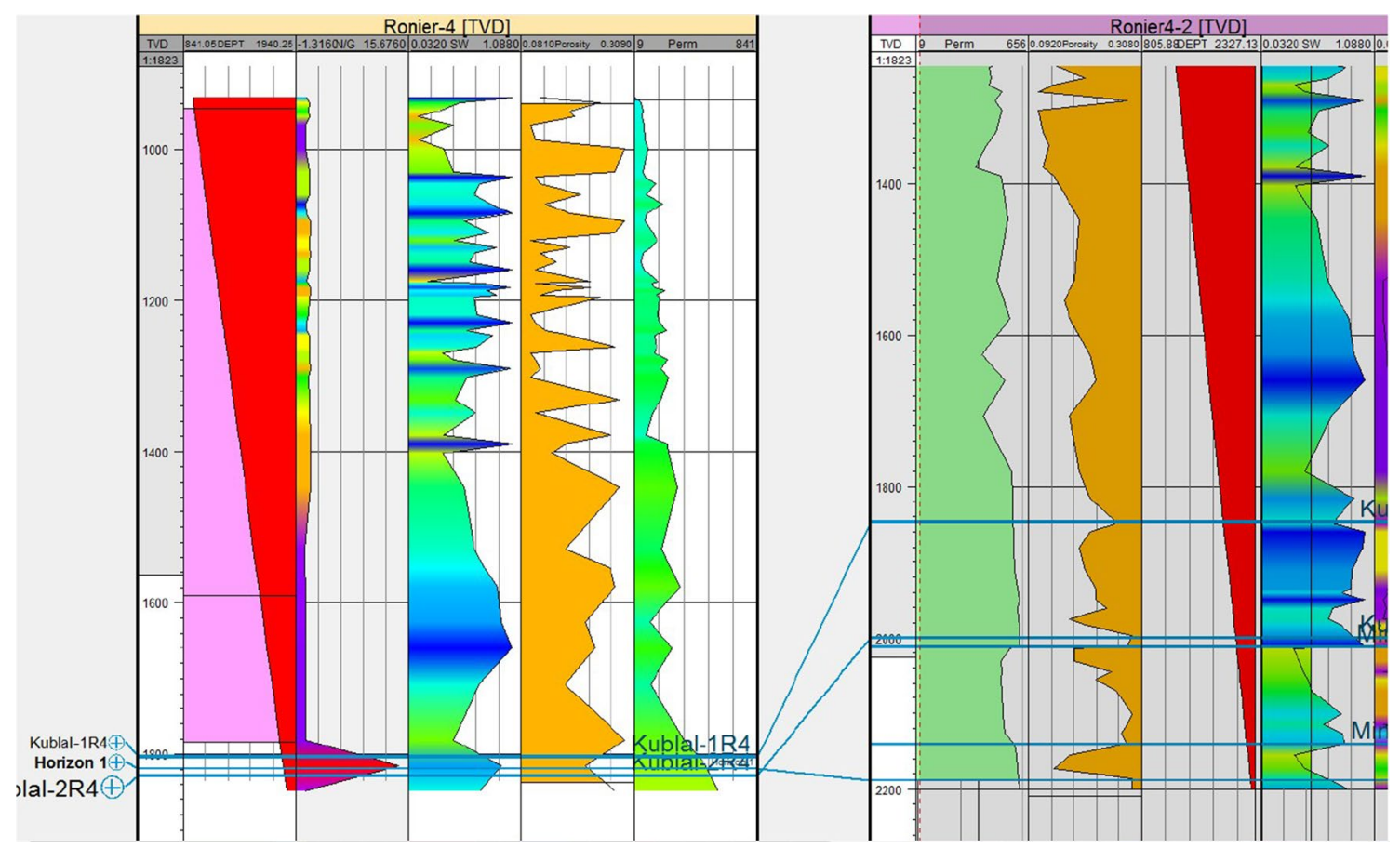

Fig. 5 The well section of Ronier 4 (from left depth, Net-To-Gross (NTG) to the right), Ronier 4-2 (from left depth to the right Net-To-Gross (NTG), Ronier 4-1 (from left depth, to the right is Net-To-Gross (NTG)

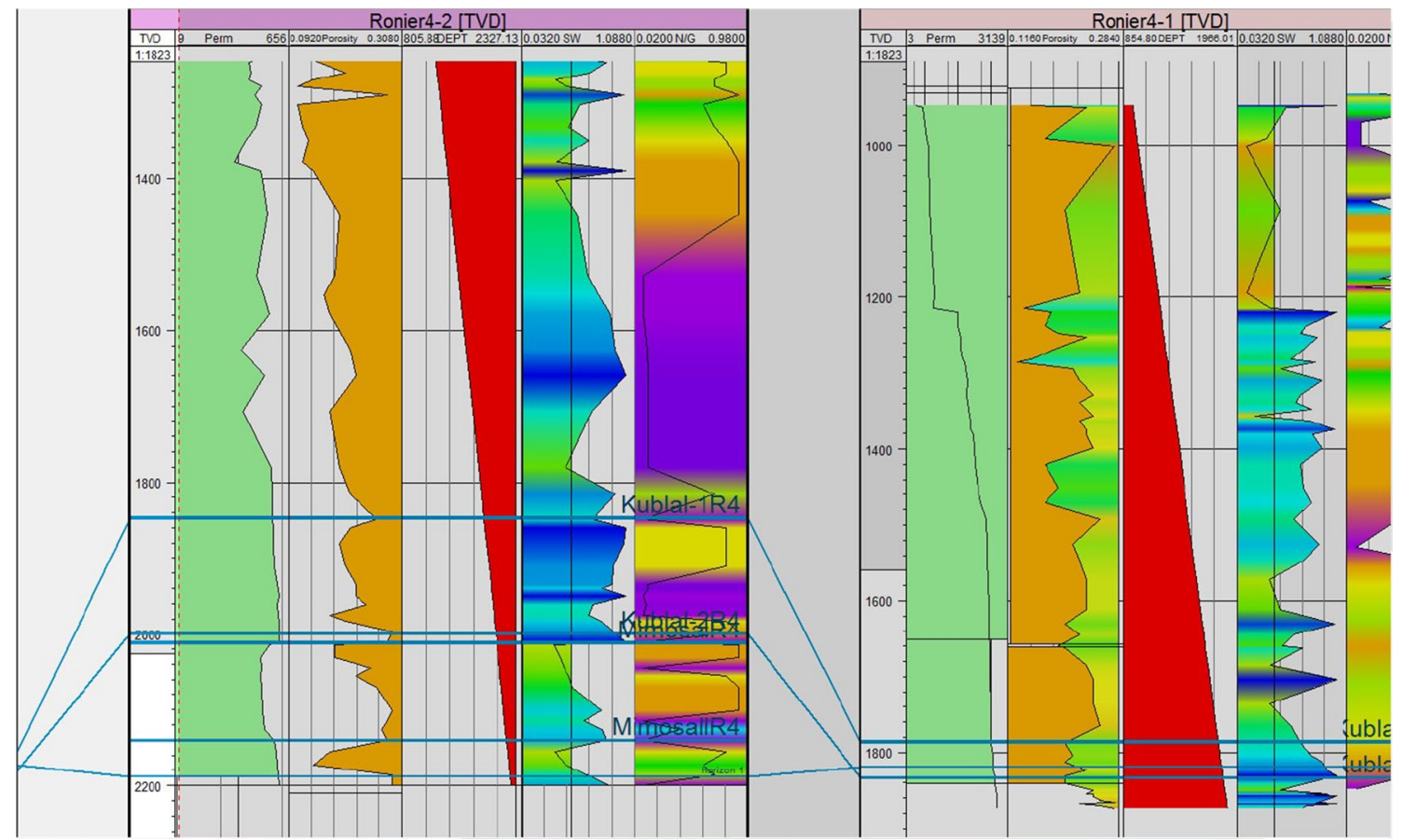

Fig. 6 The well section of Ronier 4 (from left depth, porosity to the right), Ronier 4-2 (from left depth to the right porosity), Ronier 4-1 (from left depth, to the right is porosity)

model determine the spatial distribution of oil and gas in oil and gas reservoir. Similarly, the spatial heterogeneity and uncertainty ((Kempka et al. 2018) of these parameters also bring uncertainty to the distribution and size of the reserve. In reverse, the closeness of data of reserve has the direct relation with the accuracy of the model. The 


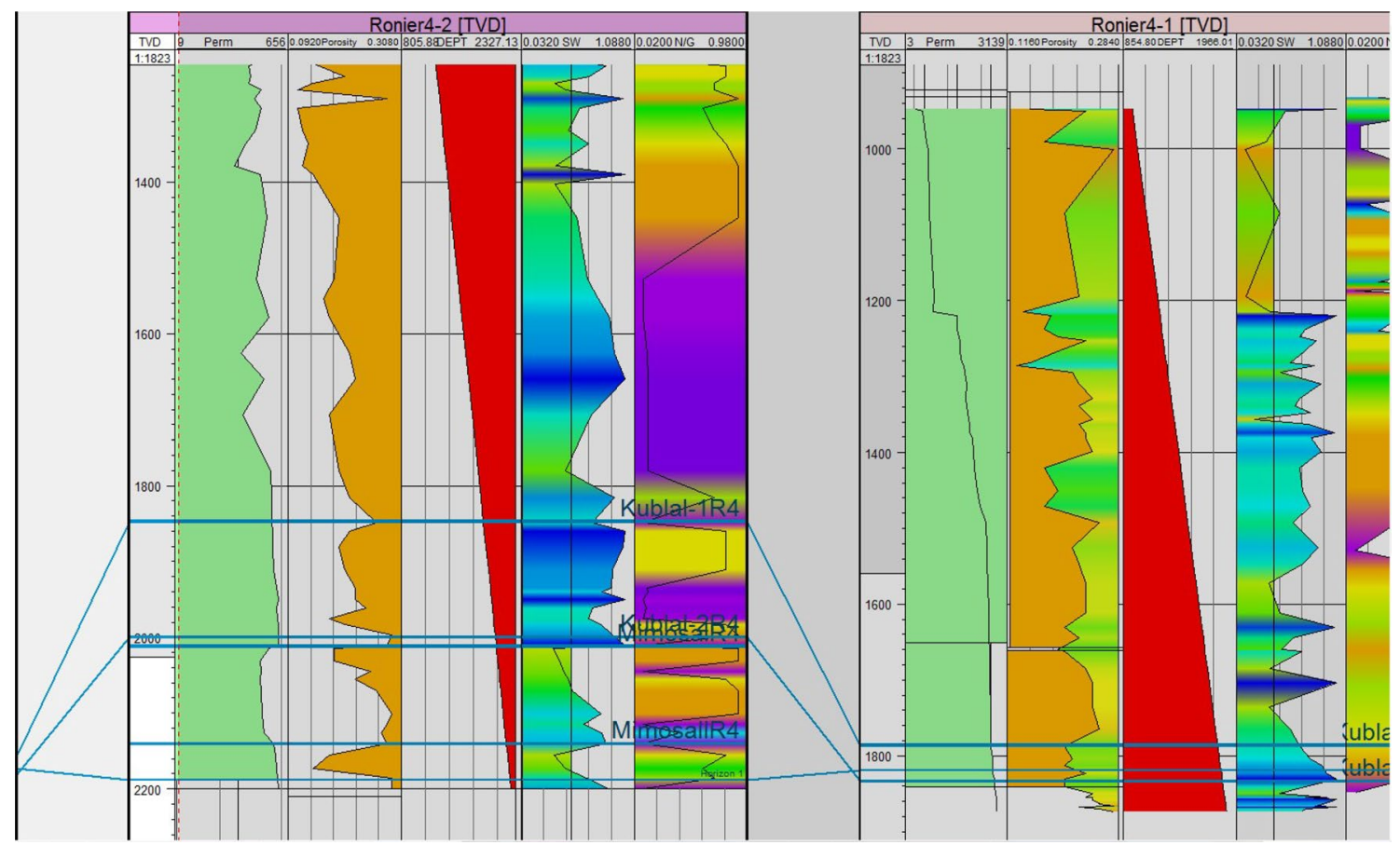

Fig. 7 The well section of Ronier 4-1 from left to the right direction (Perm, Poro, depth, Sw, Ng). The well section of Ronier 4 (from left depth, permeability to the right), Ronier 4-2 (from left depth to the right permeability), Ronier 4-1 (from left depth, to the right is permeability)

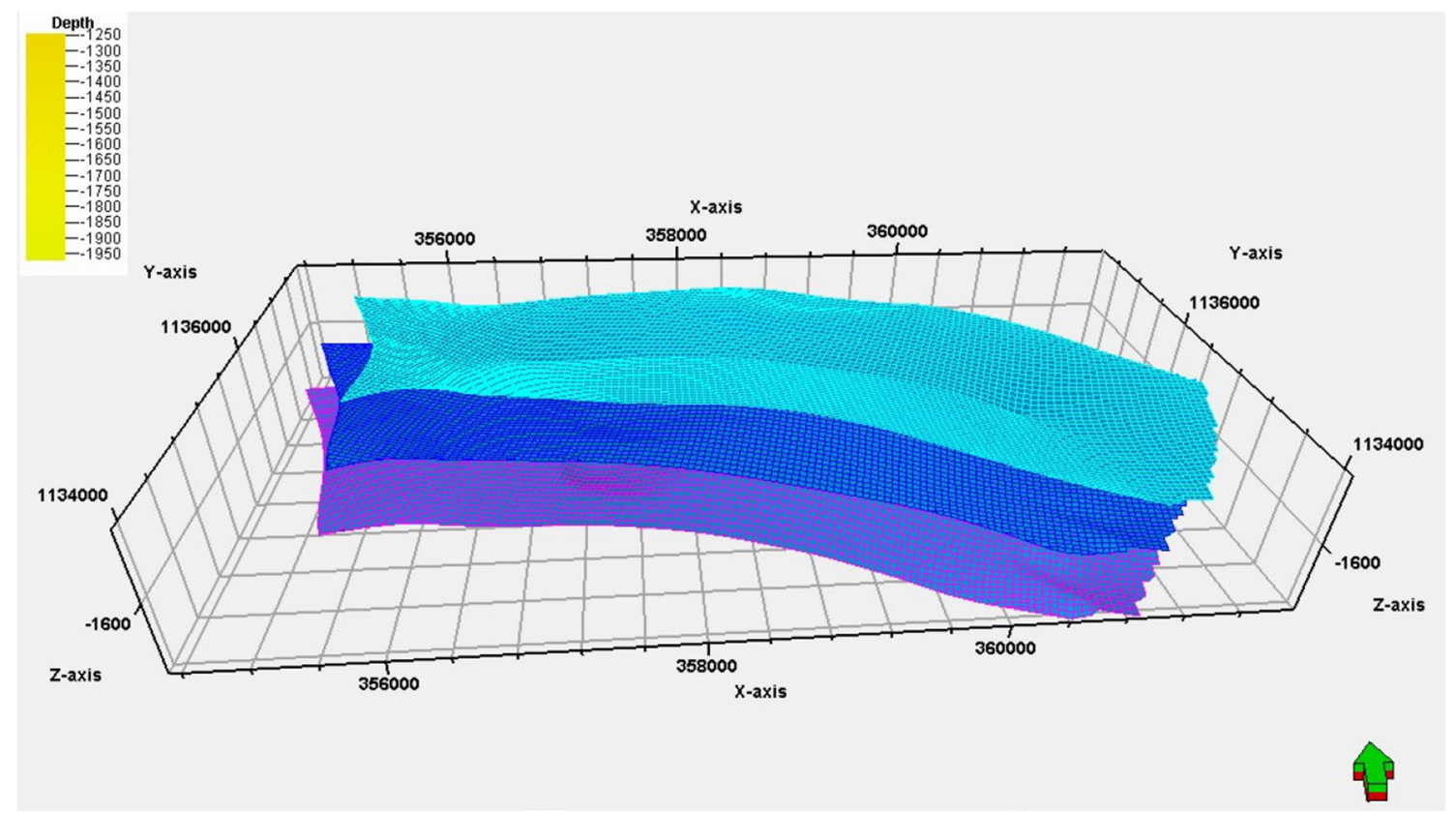

Fig. 8 3D pillar gridding skeleton of the interpreted horizon of the Ronier 4 block. The well section of Ronier 4 (from left depth, SW to the right), Ronier 4-2 (from left depth to the right SW), Ronier 4-1 (from left depth, to the right is SW) 


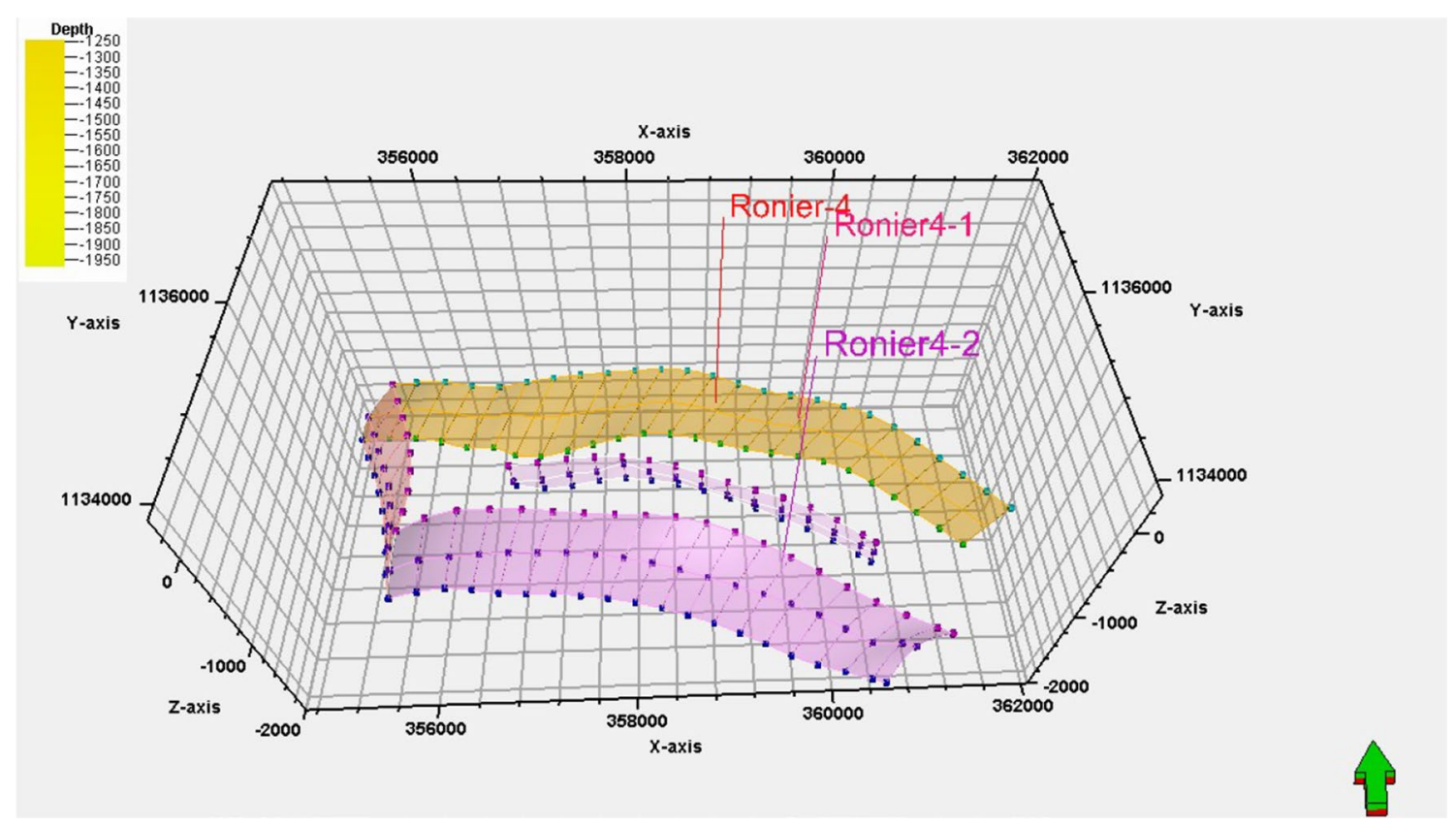

Fig. 9 3D pillar gridding skeleton of the interpreted horizon of the Ronier 4 block

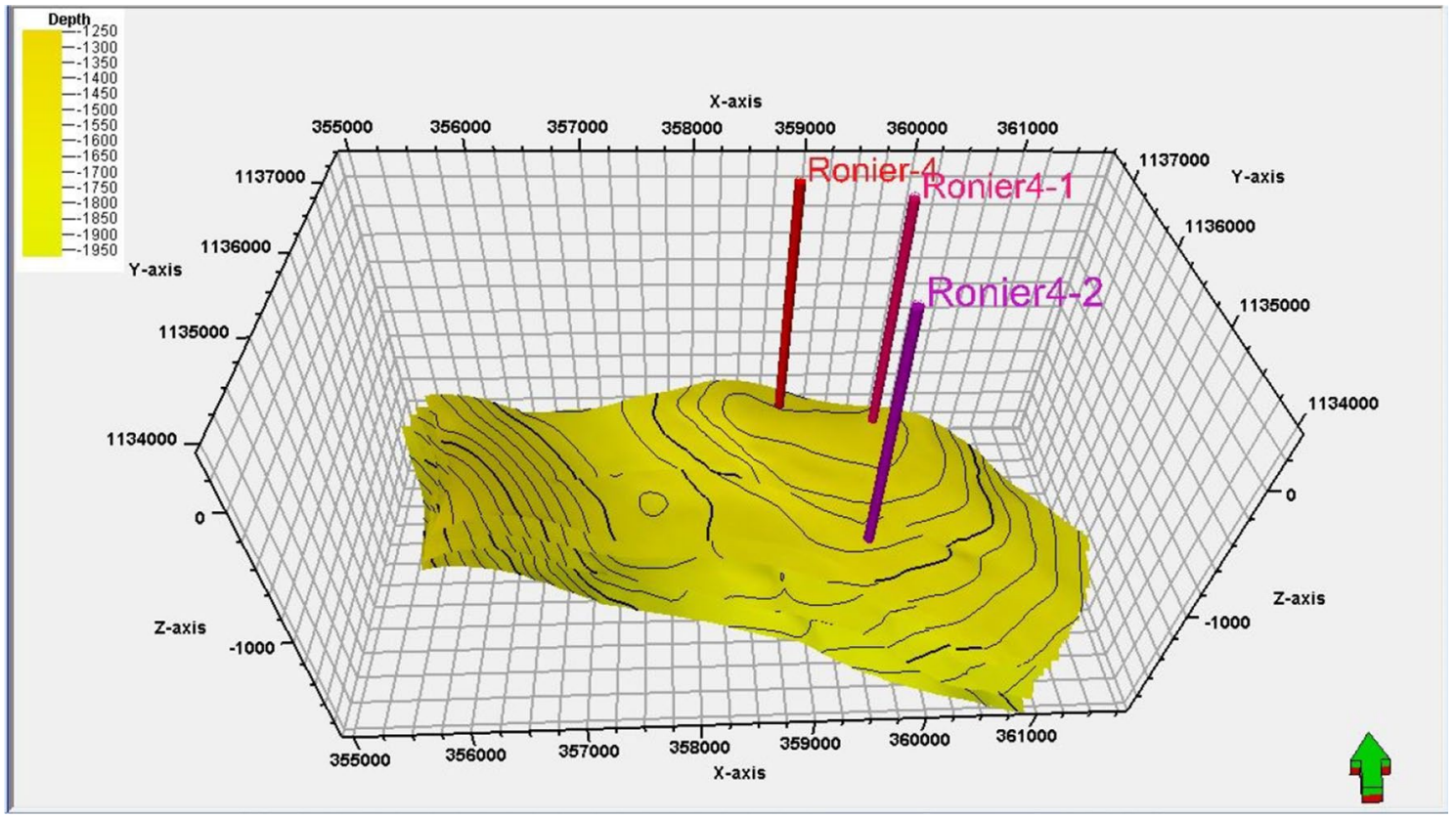

Fig. $103 \mathrm{D}$ fault modeling of the interpreted fault of the Ronier 4 block

calculation of the reserve uses the volumetric method, stratification; subsection and classification are carried out for the calculation of reserve.
This section presents the property scale-up approach used in the study. The method detailed here presents a road map to proceed when upscaling to make sure the accuracy 


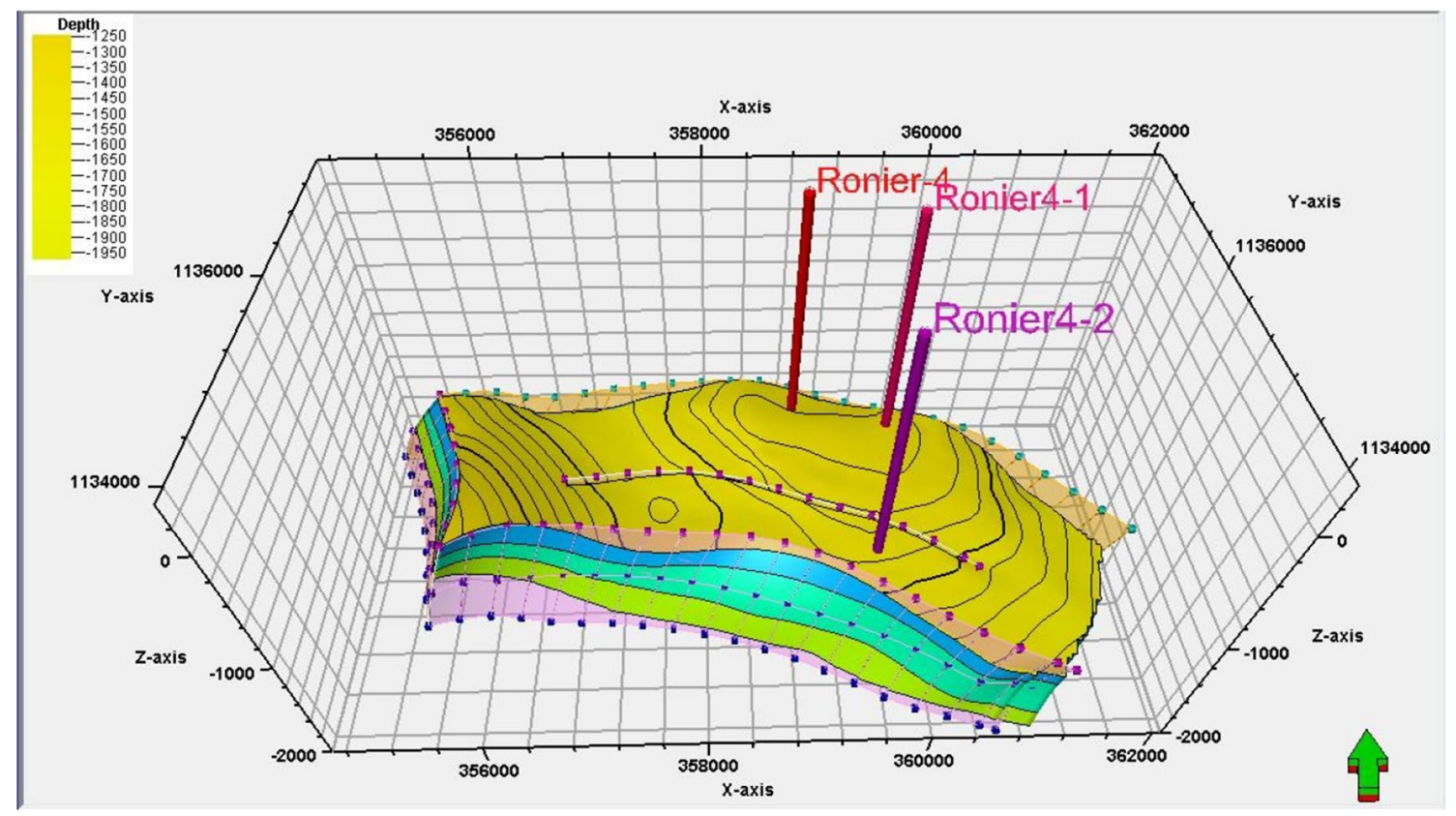

Fig. 11 A 3D structural modeling of the Ronier 4 block based on fault. A 3D structural model of the Ronier 4 block

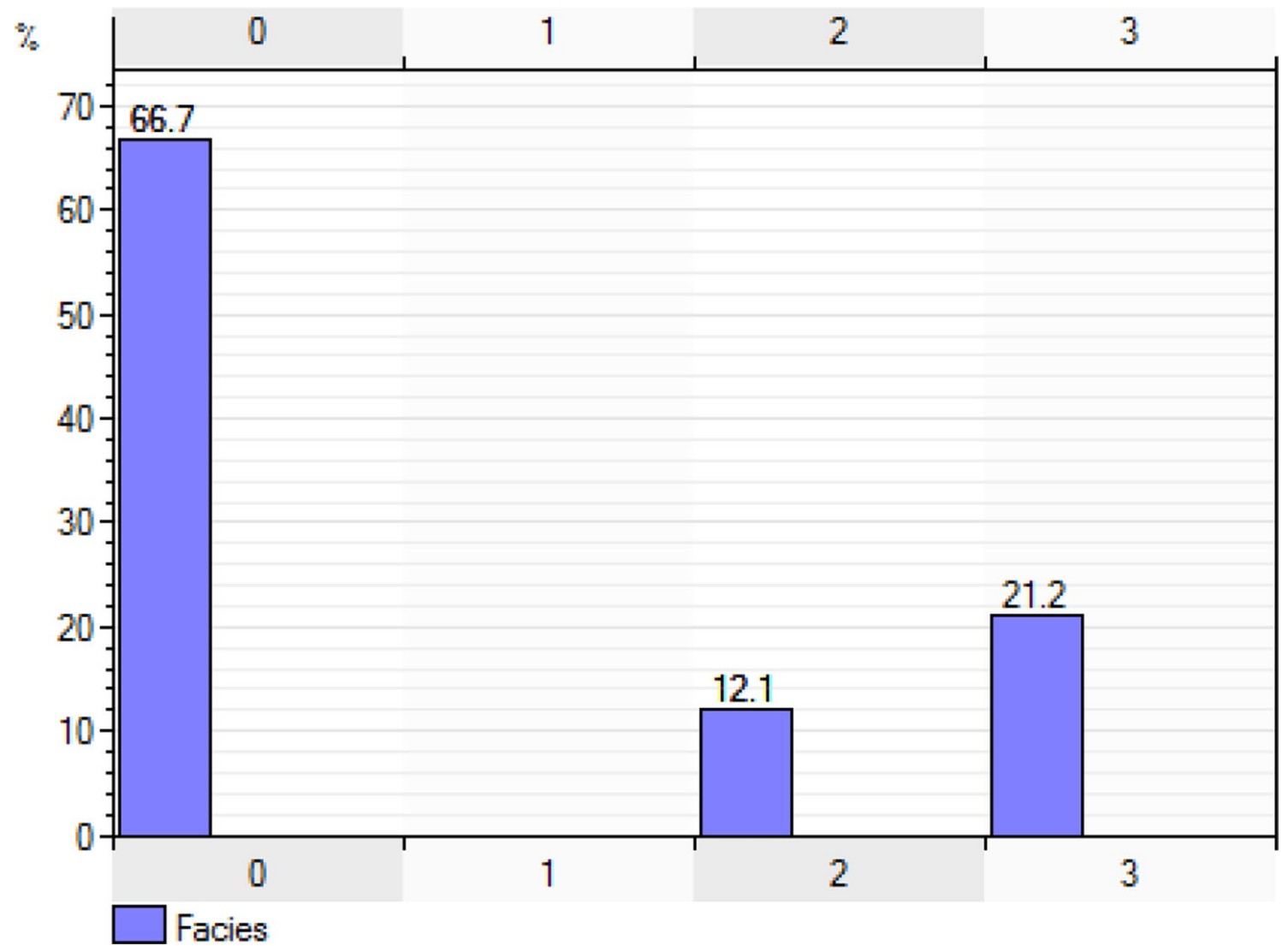

Fig. 12 Histogram shows the different facies content range for sand (0), shale (2) and sand (3). Facies scaled-up lithology well section of Ronier 4 (from left depth, Facies to the right), 


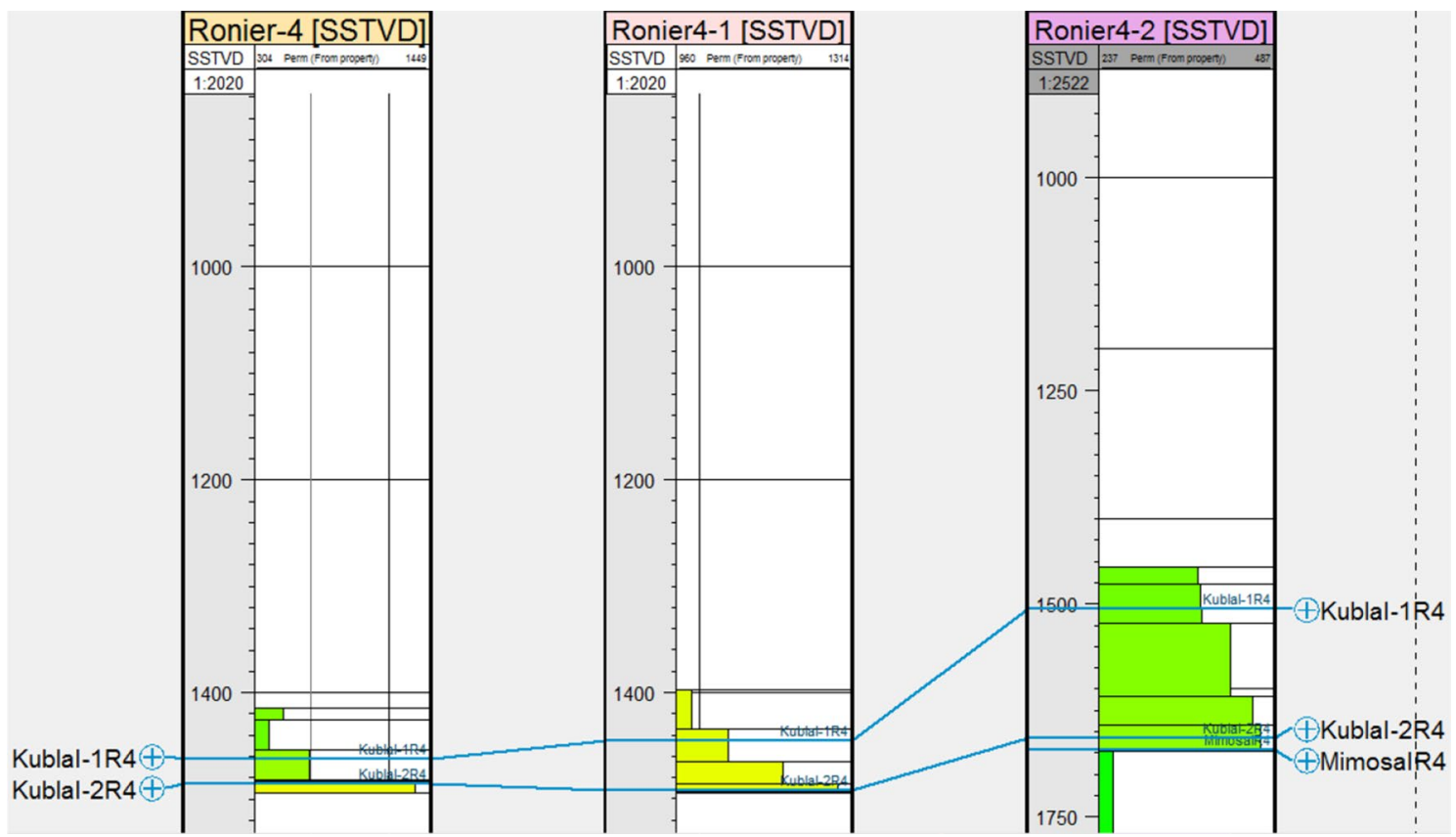

Fig. 13 Shows well section of scaled-up permeability logs. Histogram shows the different facies content range for sand (0), shale (2) and sand (3)

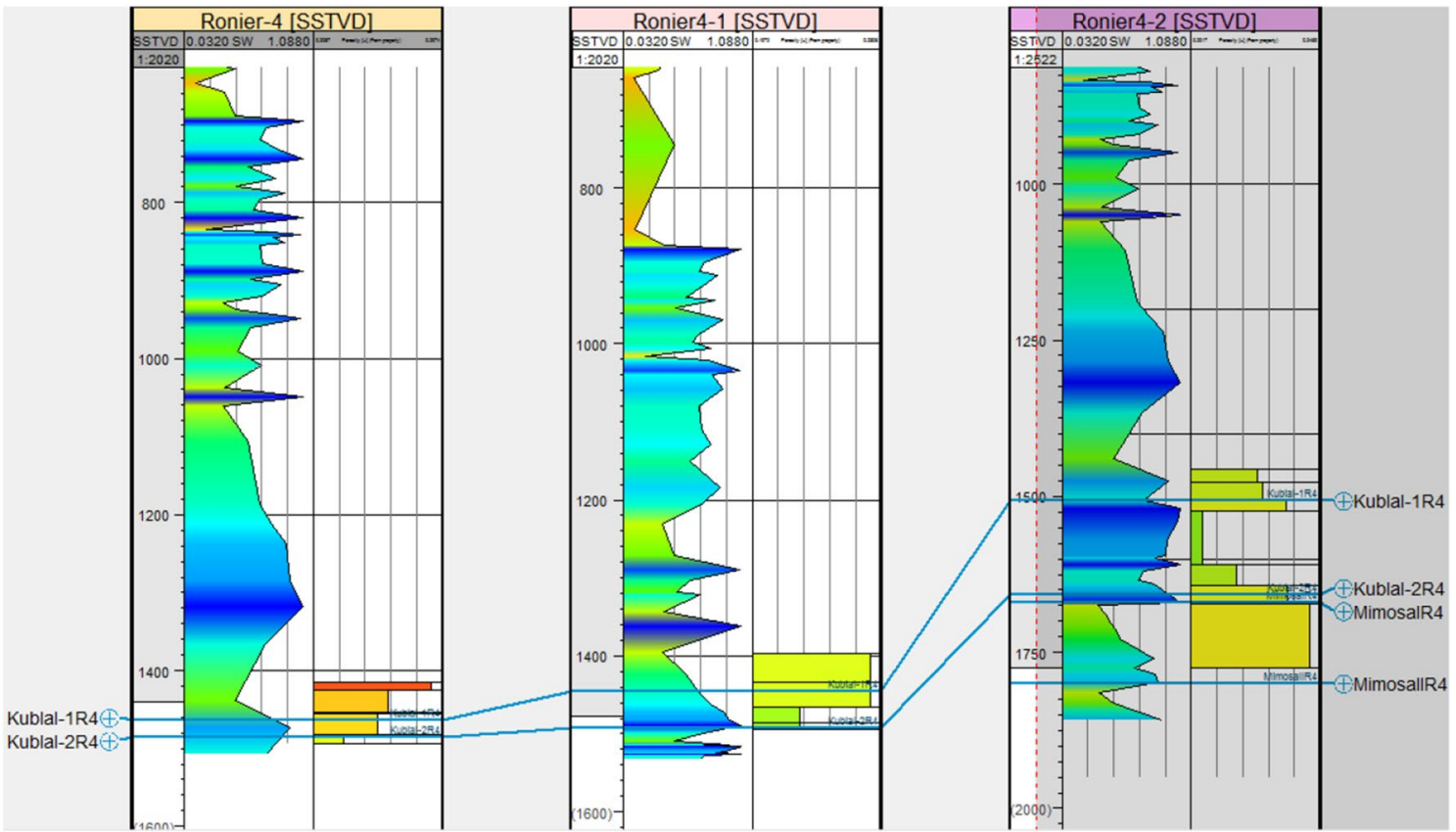

Fig. 14 Well section of scaled-up water saturation (left) and porosity (right) logs. Major range direction variogram (Facies)

in geological modeling. For the modeling development, various kinds of well logs or log information are upscaled. The purpose of upscaling well $\operatorname{logs}$ is to assign well log values to the cells in the 3D that are infiltrated by the wells. Every cell in the model can simply preserve one (1) value; finally, the log data are averaged, or upscaled 


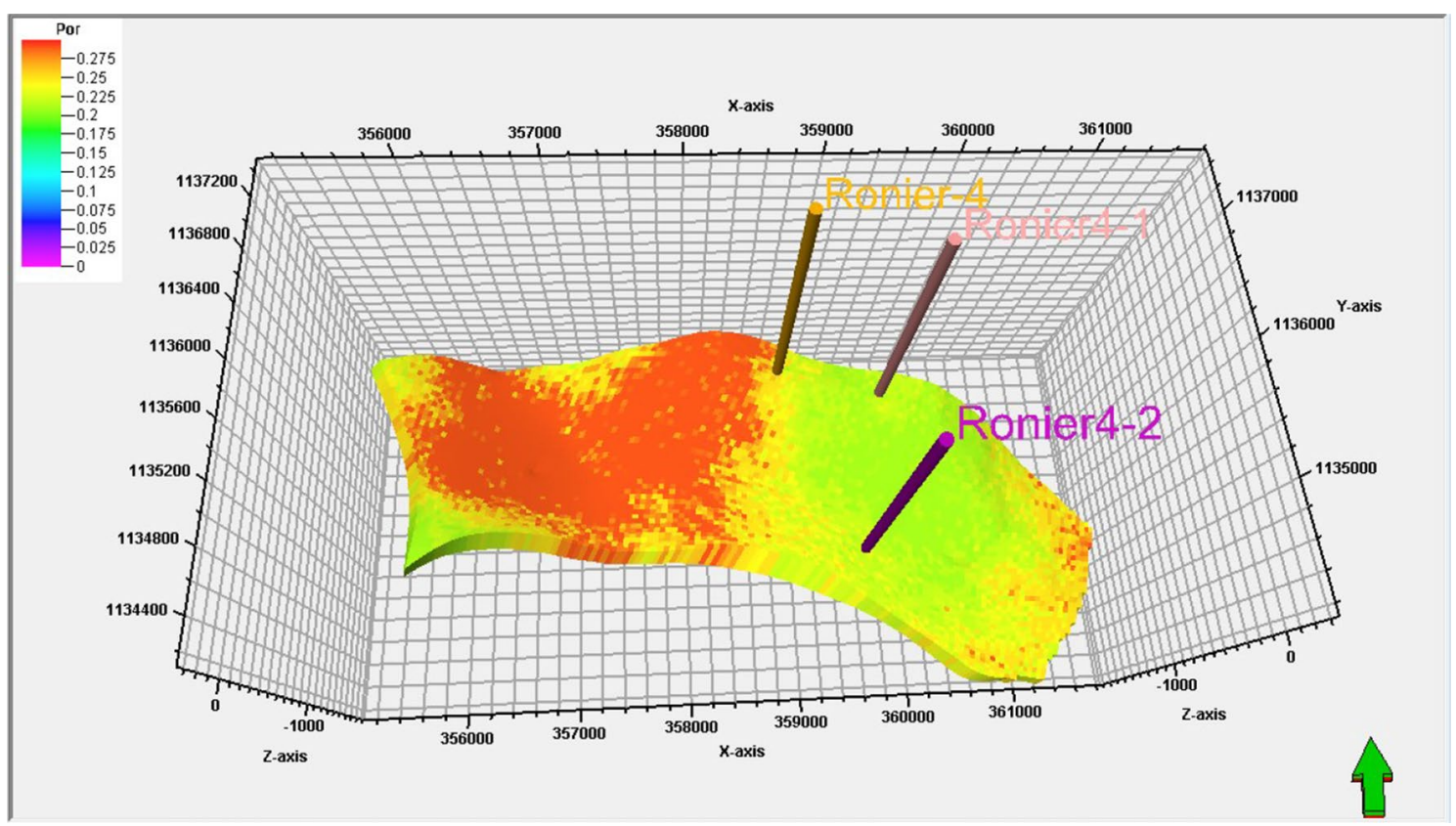

Fig. 15 3D Non-upscaled porosity distribution of the Ronier 4 block. Minor range direction variogram (Facies)

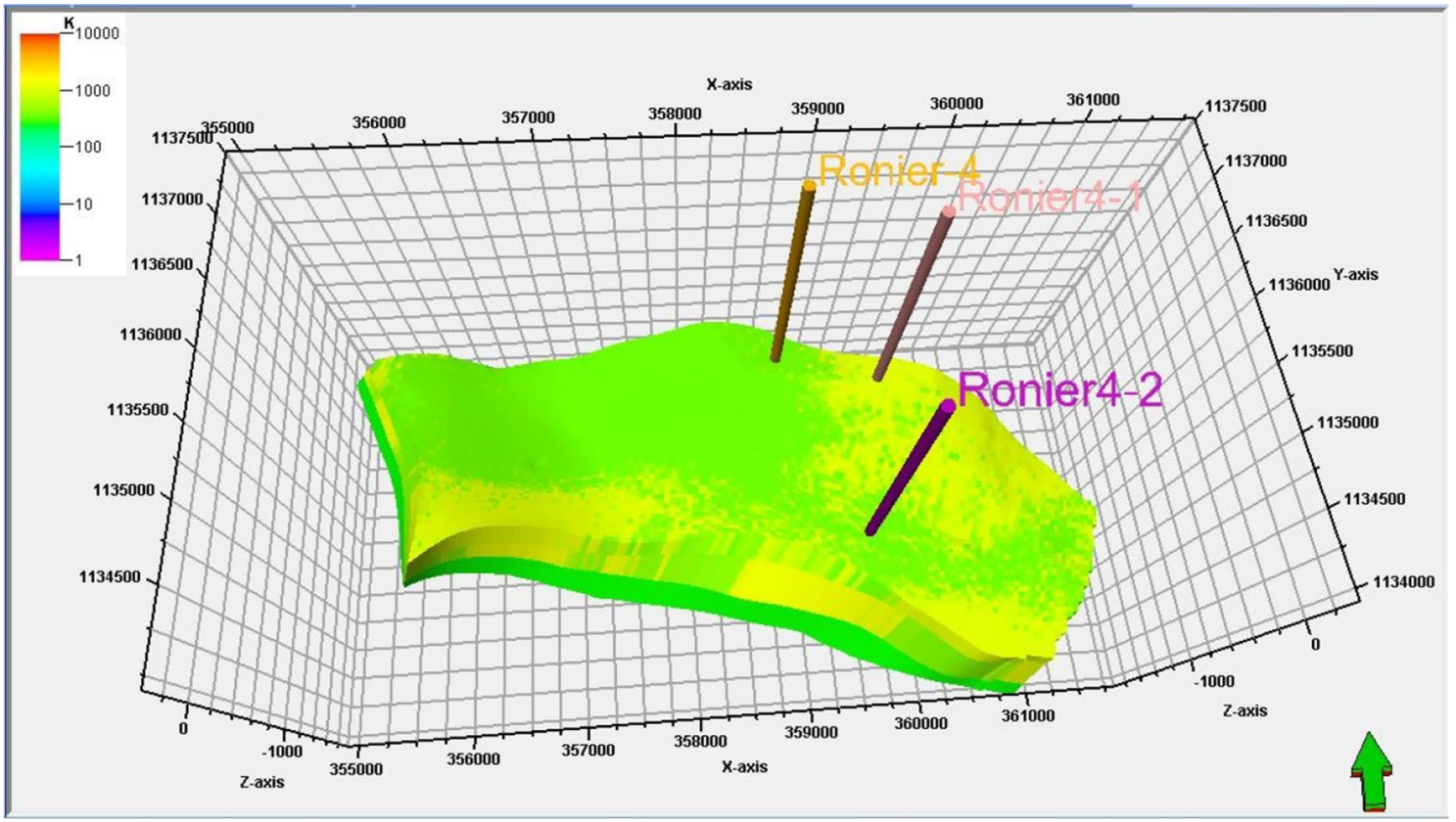

Fig. 16 3D Non-upscaled permeability distribution of the Ronier 4 block. Vertical range direction variogram (Facies)

to allocate the facies, properties data between the wells where data are not available (Figs. 12, 13, 14, 15, 16, 17, 18, 19).
The mesh spacing of the upscaling grid plane is $50 \times 50$; the longitudinal grid uses the single layer as the unit. Ronier 4 is taken as an example, in order to compare the impact 


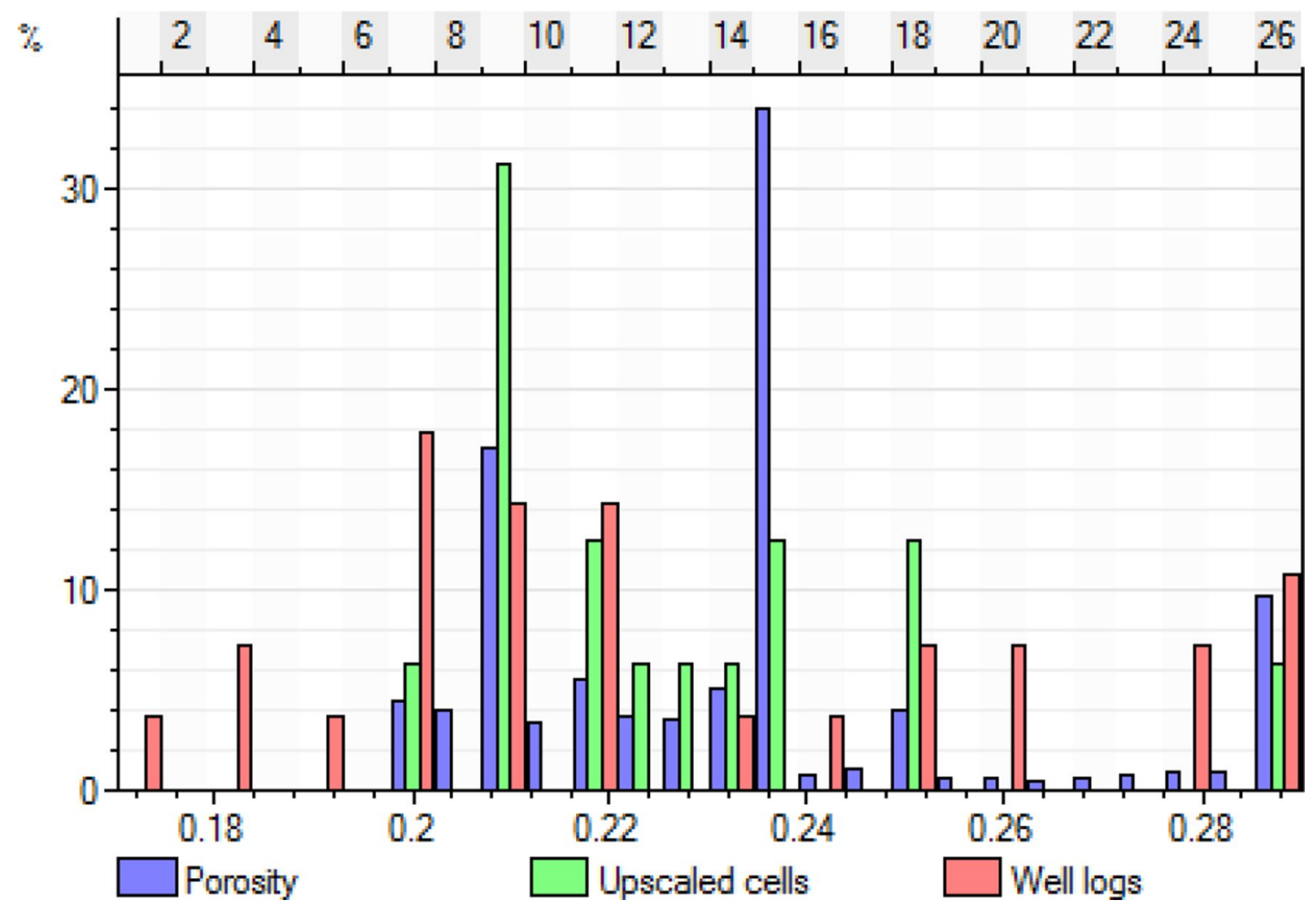

Fig. 17 Scaled-up well section of Ronier 4 NTG (from left depth, NTG to the right), Ronier 4-2 (from left depth to the right NTG), Ronier 4-1 (from left depth, to the right is NTG)

of different mesh spacing: two sets of upscaling grids (Hasan et al. 2018) are made: one set is the plane mesh spacing of $50 \times 50$; the longitudinal one defines 3 units according to the division of sedimentary units. According to the requirements of the mathematical model, the upscaled net thickness-sandstone thickness ratio model, porosity model, permeability and water saturation model need to be input. The net thickness-sandstone thickness ratio model, porosity model, permeability and water saturation model are a scalar quantity. In upscaling, the arithmetic average method and mean square root method are mainly used for upscaling. The net thickness-sandstone thickness ratio adopts the volume weighing, the porosity and permeability use the volume and the net thickness-sandstone thickness ratio weighing so that the upscaled model can reflect the geological features and the flow response of the original model indeed.
The reservoir of three blocks is the braided river delta front facies sediment, continuous distribution of sand body, thin single sand body and the sand body connectivity in the north and west direction. Because there are fewer wells and the area is significant, and the essential data do not meet the statistical requirement of variation function requirement, the variation function of Ronier reservoir is obtained through the application of seismic inversion (Fig. 20).

In Block Ronier 4, Kubla I-1 section reservoirs are far from the source and have complicated sedimentary microfacies, including mouth bar, underwater distributary channel and turbidity fan, resulting in obvious change of sand body distribution. Looking at the distribution of sand thickness, the sand body extends along the line from Well Ronier 4 to Well Ronier 4-1, and Well Ronier 4-2 sand becomes noticeably fewer and thinner. 


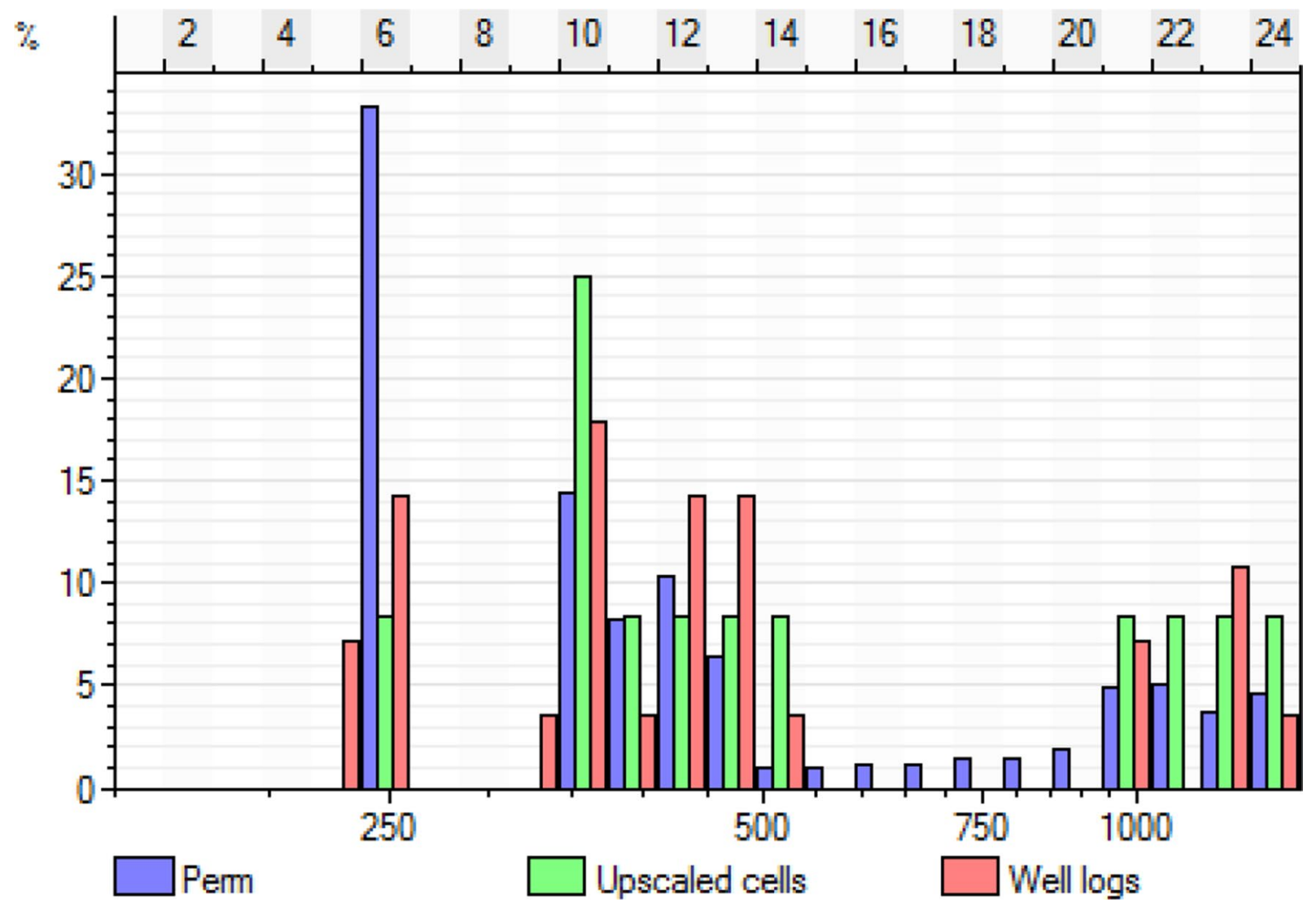

Fig. 18 This histogram shows the interpolated Permeability plus upscaled log data and raw well log data. NTG vertical direction range variogram (NTG)

The Net-To-Gross (NTG) distribution is highly concentrated in the north, center and south (1) and 0.7 on average, while the lowest range is 0.1 (Fig. 21). The porosity distribution mainly distributed between 17 to 27 and $19 \%$ on average, the Ronier 4 block has indicated good porosity value in the study Fig. 22. The permeability is mainly distributed between 460 to 1200 and $500 \mathrm{mD}$ on average. The permeability distribution is highly concentrated in the east (Ronier 4-1) and west of the scaled model. That has resulted the high permeability in the east and west direction. Due to the higher logging interpreting oil saturation, $60-72 \%$, this conflicts with the irreducible water saturation of the core obtained in the laboratory. Average water saturation is calculated $40.8 \%$ through the analysis of the core saturation of Well Ronier 4-1. Water saturation ranges between 0.5 and 1 ; mainly the first layer is highly saturated, while the saturation in the western part is seen to be decreasing (Fig. 23).

\section{Conclusion}

The result of the 3D model indicates the importance of transparency of assimilating seismic and well log data of reservoir modeling. The following conclusions can be made:

1. Lithofacies model indicated the code (0) sand content $66.69 \%$ mostly the first layer, while the code (2) shale content $12.15 \%$ mostly concentrated in the center, north and south. Finally, the code (3) sand content is $21.16 \%$. 


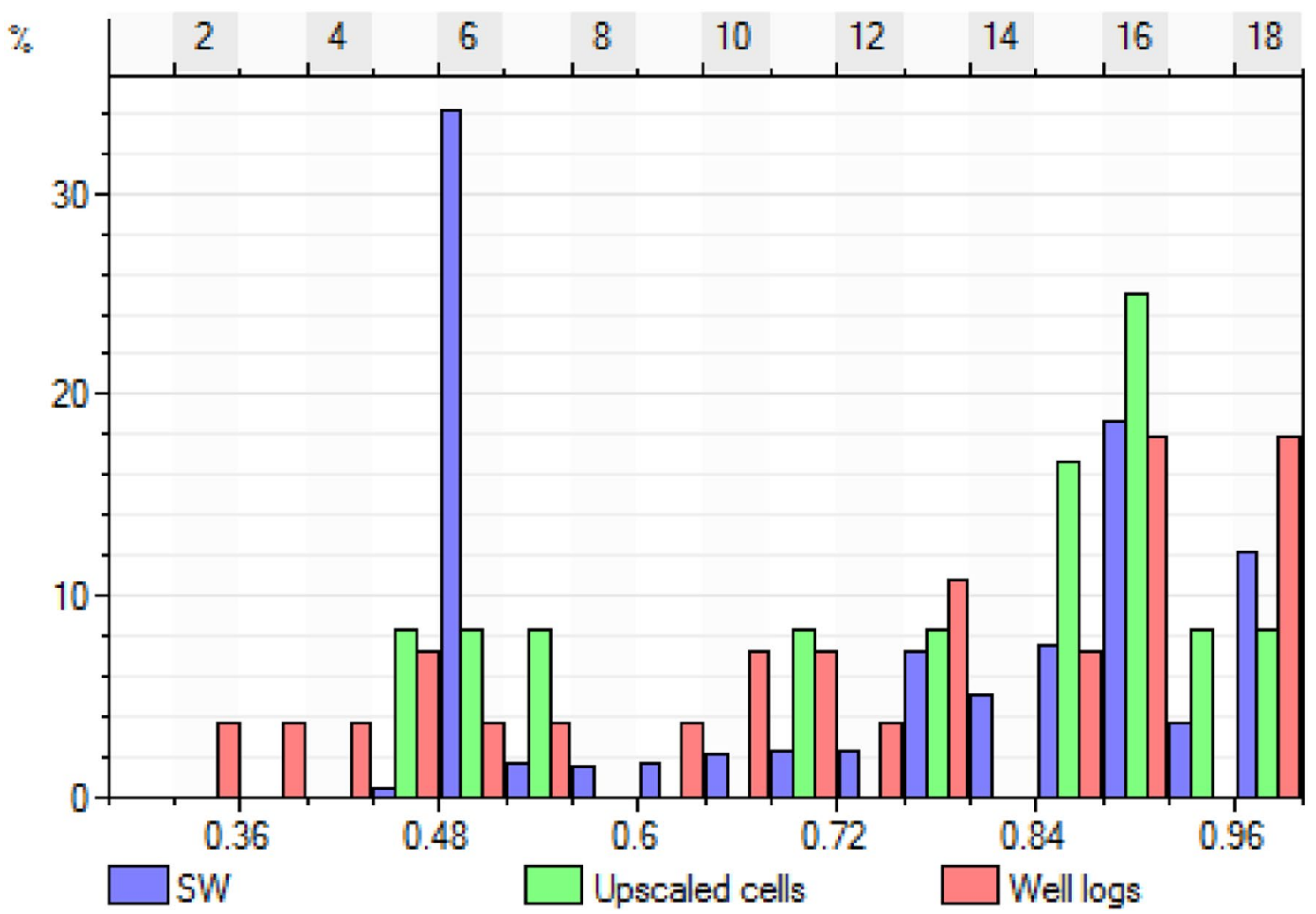

Fig. 19 This histogram shows the interpolated saturation water plus upscaled log data and raw well log data. SW vertical direction range variogram (SW)

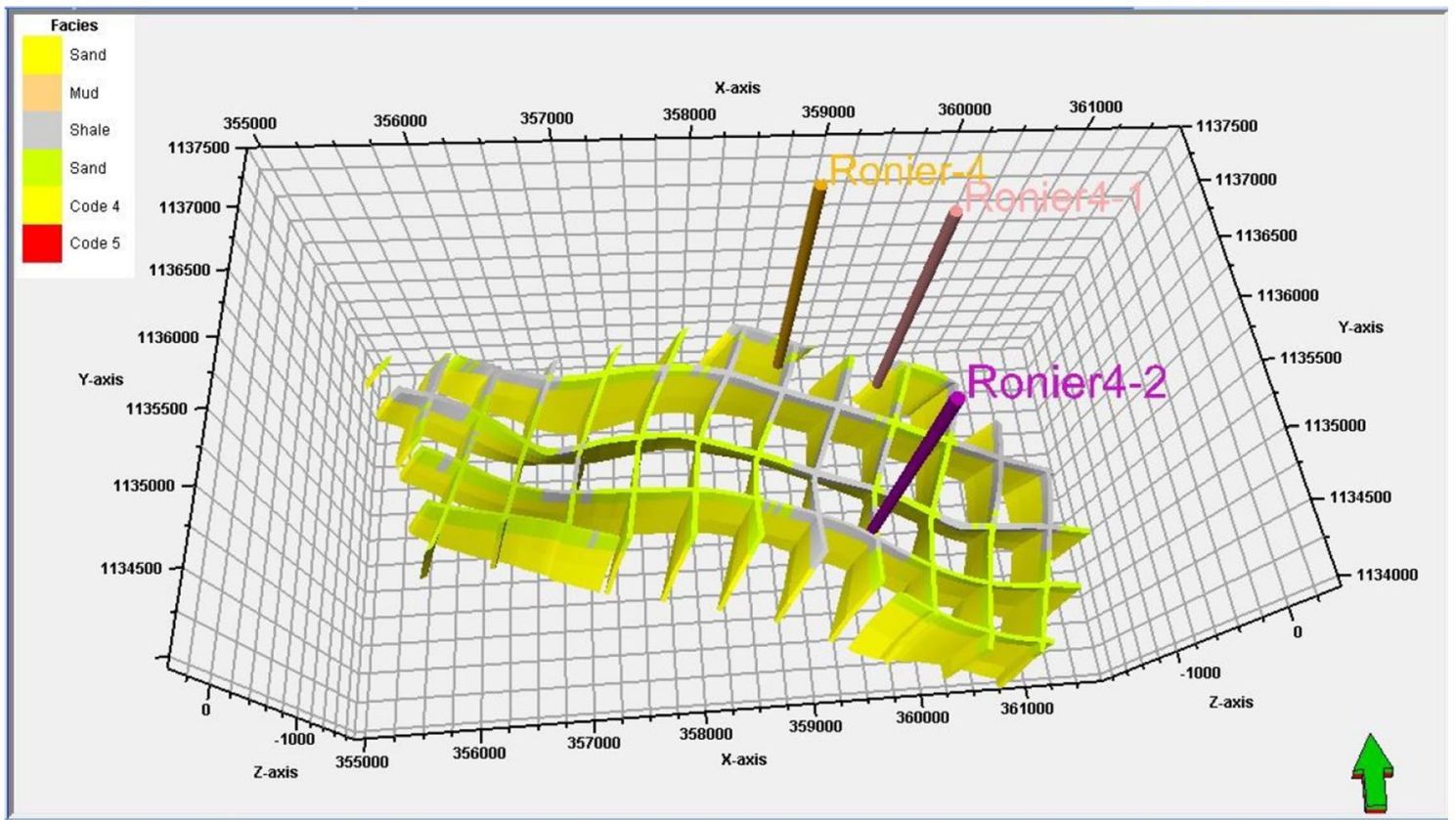

Fig. 20 3D Lithofacies model produced by Sequence Gaussian Stochastic indicator 


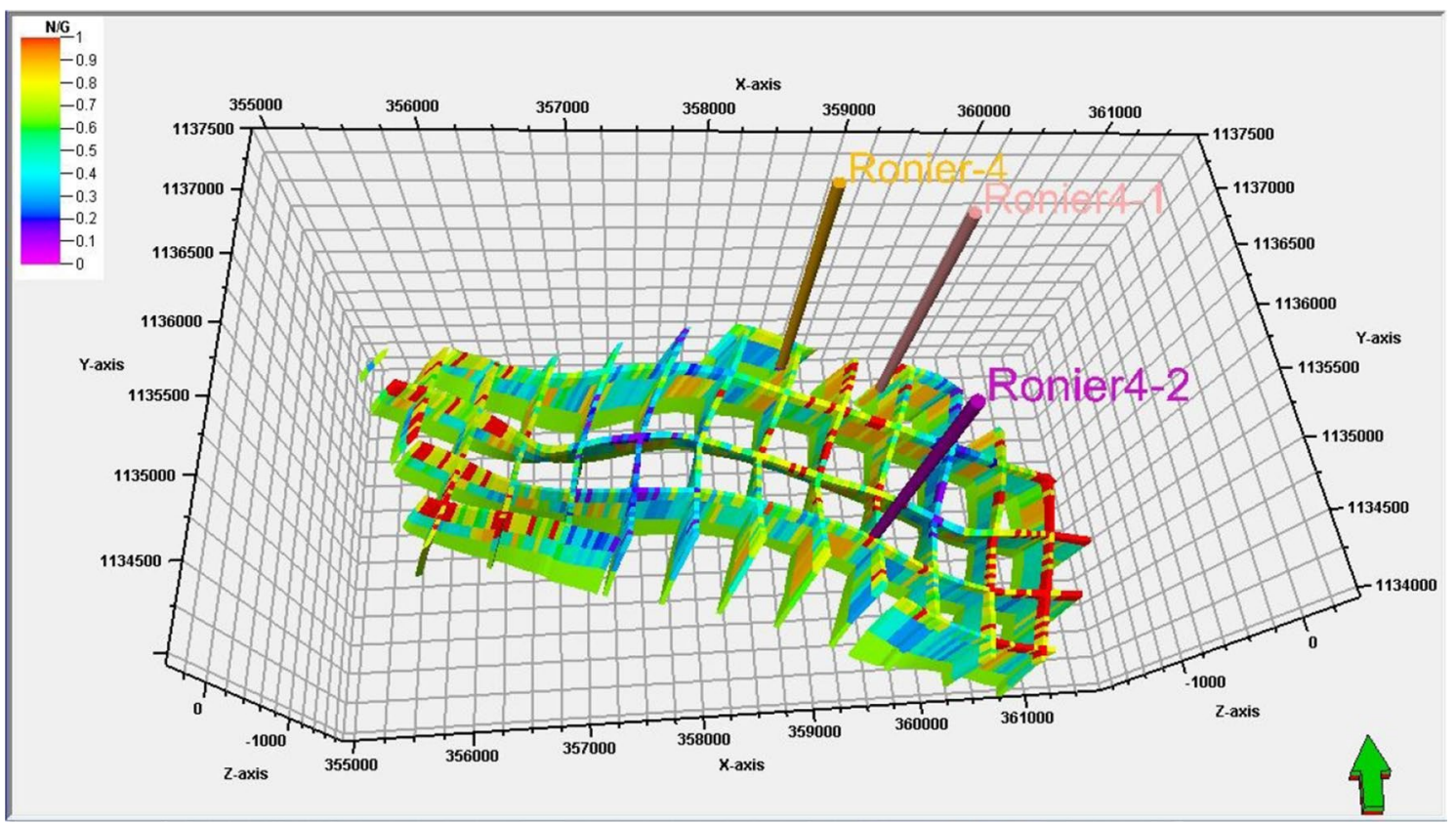

Fig. 21 3D Lithofacies upscaled model produced by Sequence Gaussian Stochastic indicator 3D upscaled NTG distribution of the Ronier 4 block

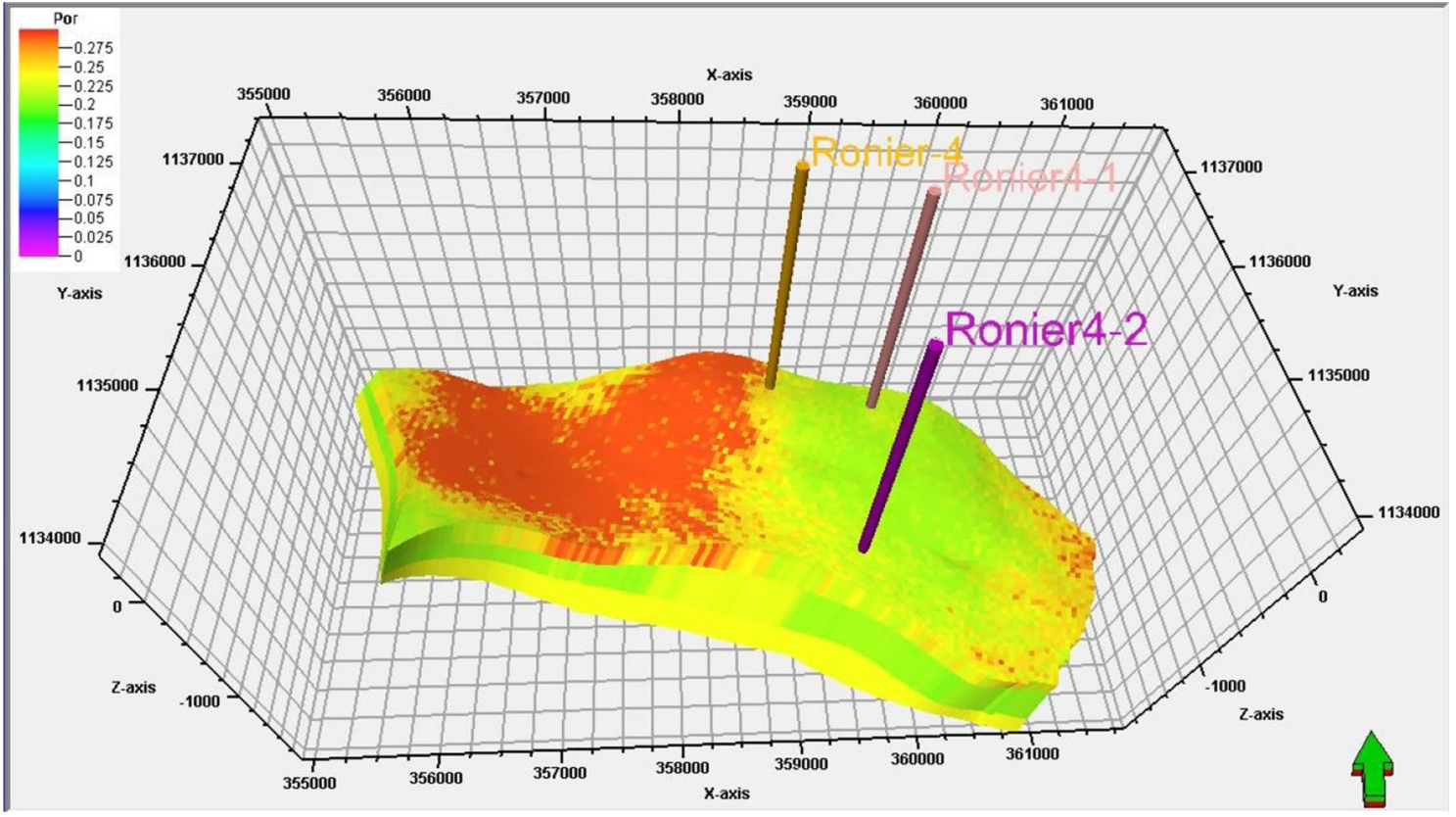

Fig. 22 Net-To-Gross (NTG) scaling the model of the Ronier 4 block

2. The geological model results of the permeability, porosity, oil saturation showed very favorably from northern and southern part as well the eastern part.
3. The Net-To-Gross distribution is highly concentrated in the north, center and south (1) and 0.7 on average, while the lowest range is 0.1 . 


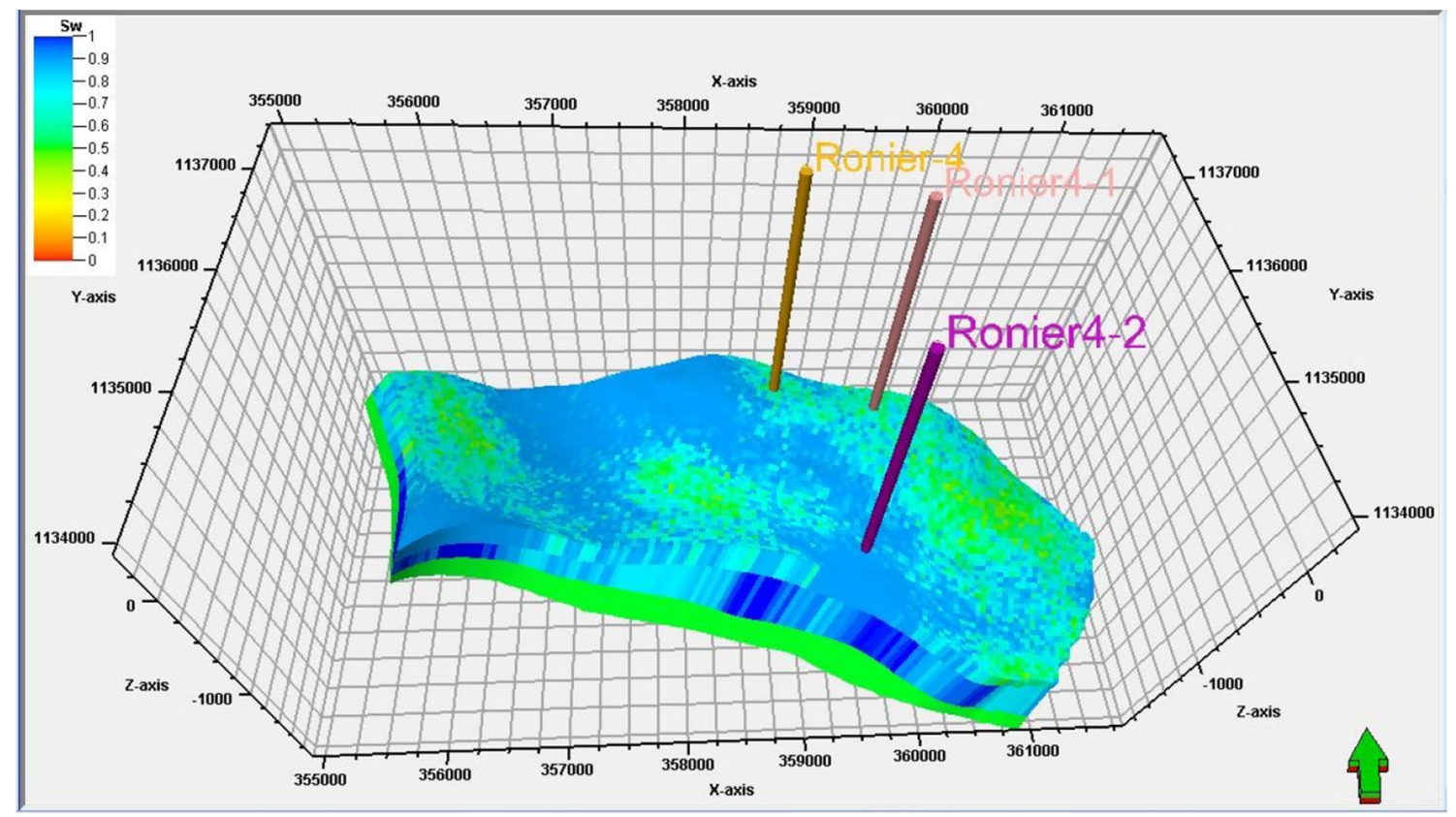

Fig. 23 3D upscaled Net-To-Gross (NTG) distribution of the Ronier 4 block

4. The study shows a good permeability range between 460 to 1200 and $500 \mathrm{mD}$ on average. With the highest porosity value of $27 \%$ and $19 \%$ on average, the reservoir indicates that it has good reservoir properties.

5. This model presents a clear road map for the reservoir geological, and it can be applied for the future development plan.

Open Access This article is distributed under the terms of the Creative Commons Attribution 4.0 International License (http://creativeco mmons.org/licenses/by/4.0/), which permits unrestricted use, distribution, and reproduction in any medium, provided you give appropriate credit to the original author(s) and the source, provide a link to the Creative Commons license, and indicate if changes were made.

\section{References}

Bai J, Shi Z, Li J, Xue L, He W (2015) Structure and tectonic evolution controls on hydrocarbon accumulation in fractured basement: a case study from Melut Basin in South Sudan and Bongor Basin in Chad. In: International conference and exhibition, Melbourne, 13-16, Australia, Society of Exploration Geophysicists, p 564

Dou L, Wang J, Wang R, Wei X (2018) Precambrian basement reservoirs: case study from the northern Bongor Basin, the Republic of Chad. J AAPG Bull Chandramani 102(9):1803-1824

Genik GJ (1992) Regional framework, structural and petroleum aspects of rift basins in Niger, Chad and the Central African Republic (C.A.R.). Elsevier Science 213(1-2):185

Hasan N, Rahman AO, Alam MS (2018) Validation and verification of CFD prediction of fluid flow of a submerged vertical round jet. Int J Eng Mater Manuf 3(2):113-121
Hourfar F, Salahshoor K, Zanbouri H, Elkamel A, Pourafshary P, Moshiri B (2018) A systematic approach for modeling of waterflooding process in the presence of geological uncertainties in oil reservoirs. Comput Chem Eng 111:66-78. https://doi. org/10.1016/j.compchemeng.2017.12.012

Ishak MA, Islam MA, Shalaby MR, Hasan N (2018) The application of seismic attributes and wheeler transformations for the geomorphological interpretation of stratigraphic surfaces: a case study of the F3 block. Dutch offshore sector. North Sea Geosci 8:79

Junyi K, Hasan N (2018) Factors that influence the Wax Deposition in Subsea Pipelines. Int J Mater Manuf 3(1):1-8

Kempka T, Norden B, Ivanova A, Lüth S (2018) Reducing uncertainty in the permeability distribution in a storage reservoir by integrated inverse modelling. In: 20th EGU General Assembly, Vienna, Austria, vol 20, p 19326

Khan MNH, Fletcher C, Evans G, He Q (2001) CFD modeling of free surface and entrainment of buoyant particles from free surface for sumberged jet systems. American Society of Mechanical Engineers, Heat Transfer Division, (Publication) HTD 369:115-120

Khan MNH, Fletcher C, Evans G, He Q (2003) CFD analysis of the mixing zone for a submerged jet system. Proc ASME Fluids Eng Div Summer Meet 1:29-34

Lorentzen R, Bhakta T, Grana D, Luo X, Valestrand R, Nævdal G (2018) History matching of real production and seismic data in The Norne Field. In: ECMOR XVI-16th European conference on the mathematics of oil recovery

Misaghian N, Assareh M, Sadeghi M (2018) An upscaling approach using adaptive multi-resolution upgridding and automated relative permeability adjustment. Comput Geosci 22(1):261-282. https:// doi.org/10.1007/s10596-017-9688-2

Sedaghat MS, Matthai SM, Azizmohammadi SA (2018) Tensorial Fracture-matrix ensemble relative permeabilities in naturally fractured reservoirs: evidence from discrete fracture and matrix simulations. In: Third EAGE workshop on naturally fractured

Sern WK, Takriff MS, Kamarudin SK, Talib MZM, Hasan N (2012) Numerical simulation of fluid flow behaviour on scale up of oscillatory baffled column. J Eng Sci Technol 7:119-130 
Shellnutt JG, Lee TY, Yang CC, Hu ST, Wu JC, Wang KL, Lo CH (2015) Late Permian mafic rocks identified within the Doba basin of southern Chad and their relationship to the boundary of the Saharan Metacraton. Geol Mag 152:1073-1084

Tan M, Zhu X, Geng M, Zhu S, Liu W (2017) The occurrence and transformation of lacustrine sediment gravity flow related to depositional variation and paleoclimate in the Lower Cretaceous Prosopis Formation of the Bongor Basin, Chad. J Afr Earth Sci 134:134-148. https://doi.org/10.1016/j.jafrearsci .2017 .06 .003

Witt P, Khan MNH, Brooks G (2007) CFD modelling of heat transfer in supersonic nozzles for magnesium production. In: TMS annual meeting, pp 123-132
Zhalehrajabi E, Rahmanian N, Hasan N (2014) Effects of mesh grid and turbulence models on heat transfer coefficient in a convergent-divergent nozzle. Asia Pac J Chem Eng 9:265-271. https ://goo.gl/uNz2jm

Publisher's Note Springer Nature remains neutral with regard to jurisdictional claims in published maps and institutional affiliations. 